\title{
Integrated Water Resource Management (IWRM): A Case Study of Durlung Watershed, Bagmati Zone, Nepal
}

\author{
Sabita Aryal Khanna, Kundan Lal Shrestha, Ramesh Kumar Maskey, \\ Alaka Lamsal, Keshab Pyakurel, Manisha Poudyal, Manish Ranjit, \\ Drishtant Karki, Ranjan Aryal and Ashish Shrestha
}

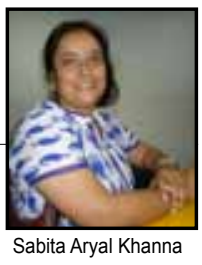

Abstract: Water in Nepal is a key strategic natural resource, which has potential to leads all round development and economic growth of the country. Integrated Water Resource Management (IWRM) is a holistic management approach, integrating land water interaction, socio-economic groups, upstream downstream relations, indigenous knowledge, and institutions built up, along the temporal dimensions based on an agreed set of principles. It is a Bottom-up decentralized approach for the management of water resources. IWRM is a challenge to conventional practices, attitudes and professional certainties. It confronts entrenched sectoral interest and requires that the water resources are managed holistically for the benefits of all.

The broad objective of the multidisciplinary study was to assess the possibilities of human dimensions of water resource development and its management. Water resource accounting is done by the collection of water resources data through participatory group formation. Scientific data of hydro and metrological stations was also acquired. Hydrological modeling tools were also used. Feasibility of hydropower plant and potential of power production in the basin was readily estimated.

Total daily discharge of the Durlung Watershed was estimated on an average as 157 Million Liters. Rivers of the watershed are turbulent, unsteady and flowing with very high current, which can be utilized by local people for low cost drinking water, tourism, irrigation and hydropower generation. Micro-hydropower production possibilities in Ratan and Deuta River has shown multidimensional positive impacts on socio-economic development of the region level of community partnership in IWRM and synchronization with the Local, District and National level institutional framework for Basin Management was observed to be satisfactory. Participatory research was carried out to identify water resource base with school and community partnership. Community motive, their difficulties and gaps in community level organization were identified. Capabilities of community, to take over the responsibilities of IWRM concept, there is a lot more need of training and capacity building for now.

Keywords: IWRM, Social Accounting, Community Based WaterResource Development and Management(CBWRDM), Participatory Group Formation and Mobilization Methods (PGFMM), Community Partnership, Participatory Research, Institutionalization, Nepal

\section{Introduction}

Tntegrated Water Resources Management (IWRM) is a process of sustainable multi-sectoral development and management of water for maximum economic and social welfare in an equitable manner with due consideration of vital ecosystems and the environment. IWRM is a process which promotes the multi-sectoral development and management of water in order to maximize economic and social welfare in an equitable manner without compromising the sustainability of vital ecosystems and the environment (GWP 2000). IWRM accounts for the hydrological cycle, quality and quantity concerns, diversity of users and administrative responsibilities at various scales, distribution of resources and temporal variability, connections to land use and transboundary claims (Gumbo, B., and Van der Zaag, P., 2002). IWRM further intends to bring together and broaden the range of environmental and social values (e.g. biodiversity, social and cultural) and highlights the importance of institutions relating to water (Bellamy and Johnson 2000; Chenoweth et al. 2001; Cortner and Moote 1994). Adaptive management is closely aligned to IWRM as a means of addressing resource complexity and uncertainty in management by highlighting the roles of experimentation, action and learning (e.g. Jeffrey and Gearey 2006; Galaz 2007;
Ingram 2008; Timmerman et al. 2008).

Historically integrated water resource management was most significantly taken into consideration after the Dublin Conference on Water and Environment in 1992. The Second World Water Forum \& Ministerial Conference held in Hague, Netherland in 2000 leads to Third World Water Forum held in Kyoto, Japan in 2003 so on. Kyoto 2003 highlighted the involvement of indigenous people in the management of the resources. (Moriarty and Butterworth, 2003). IWRM indicators tend to focus on Millennium Development Goal targets $7 \mathrm{~A}$ and $7 \mathrm{~B}$ that address issues of environmental sustainability (UN, 2012). Official figures indicate that Nepal's Millennium Development Goal (MDG) targets of achieving 73\% coverage in water supply and 53\% coverage in sanitation by 2015 will be easily surpassed (UNCTN 2002). Water Resources Strategy, 2002 realized the need of adopting an Integrated National Water Resources Policy. National IWRM Plan should describe the current way of water resources development and management in terms of decisions made and actions taken in view of future result (Diana et.al. 2015). The Plan outlines the country's steps in terms of decisions and actions taken to move from where it is now to intended target, with milestones and time frames (GPW, 2004).

Nepal is endowed with abundant water resource with an average annual precipitation averaged at $1,600 \mathrm{~mm}$ (Alford 1992). Thus water is the key 
strategic natural resource bearing the capacity to trigger all around development and economic growth of the country (WECS 2003). Nepal government on realizing the importance of IWRM and still working on to make principle theme of the National Water Plan (2005). Water Resource Act (1992) and Water Resource Regulation (1993) are the main legal document for water resource management in Nepal. Water Resources Act 1992 has given the District Water Resource Committee (DWRC) the authority on decision making for water allocations. Nepal Water Resources Strategy (2002), had set goals for environmental protection based on three time frames: within 5 years, strengthening institutions for watershed management and ecosystem protection; within 15 years, implement full scale watershed management and aquatic ecosystem activities; within 25 years, make watersheds and aquatic ecosystems sustainable. However, a separate National Water Policy Document is yet to be formulated. Quevauviller (2010) reflects that there is a knowledge gap between scientists and policy-makers in IWRM to result efficient and holistic management.

Institutions of Nepal Government in water allocation are categorized at three levels. Centrally the National Water Resource Development Council is the highest authority for decision making on water related issues. WECS is the coordinating body. National Water Resource Development Committee (NWRDC) makes policies and plans for water resource management which will be implemented through district and village level institutions. At the district level, the District Water Resource Committee (DWRC) is made up of representatives from water related line agencies at the district level organizations and is hosted by the District Development Office (DDO). DDC coordinates with VDC level institutions and further Water User groups in villages and clusters. Water User groups are the local level institution for the management of water resources (Water Resources Strategy, 2002).

Poverty in Nepal is deep rooted and has existed for decades. Nepal is one of the poorest countries in South Asia. It has a rank of 144 in Human Development Index (HDI) of 0.553 (UNDP, 2009). However, the poverty situation throughout the country is not the same. There is a high disparity in development and poverty reduction trends in rural and urban areas. The poverty distribution is very high in the rural areas, especially in Mountainous and Hilly regions of the country. (IMF 2006). IWRM is the holistic management of water resources which is developed to provide basic human rights like access to safe drinking water and increase the agricultural production in a sustainable way, ensuring multiple uses of water and irrigation facilities. IWRM implementation at basin level will be helpful to meet the national goals, millennium development goals, and sustainable agricultural practices. However, this vision has just remained in text, significant contributions of water have not been deployed for the development of the nation. Basic requirements for bringing in the process of IWRM are twofold. On the one hand, there is a requirement to integrate information about the natural system, for example, integration of information of the water resources, agricultural, and ecological systems. On the other hand, there is a need for an integrated institutional response as the management responsibilities of different components of the natural systems lie with different national agencies (Gupta 2004).

The popular Participatory Watershed Management (PWM) approach has been implemented only with the involvement of the public in the decision making process (Rowe et al 2000 and Conley et al 2003), and has been employed in Nepal for soil and water conservation (Sharma, 1999). PWM enabled the communities to overcome problems and gain more control over their livelihoods, being a 'steward' of the environment. Local institutions should be involved to manage and conserve natural resources (Kenge 2009).

Community partnership is "by the people and for the people" approach. It is a recent and bottom-up approach for the management of resources in Nepal. Farmer Managed Irrigation System (FEMIS) is an example of the success of the bottom-up approach for the management of irrigation at the local level, which has reduced the burden of the government over maintenance, operation, management of infrastructure, and attainment of sustainability (Ostrom,1990). Thus recently, GON has also adopted policies to promote public/private sector participation in the development of hydropower (Hydropower Development Policy 1992).

Solving problems in managing natural resource in watershed through community participation has been highly recognized particularly in solving forest and resource uses in Nepal (Seesomonn, 2010). Empowering local people has been found as a suitable way to handle problems. Community Based Water Resource Development and Management (CBWRDM) is an important parameter for the successful implementation of IWRM.. The idea bases on the fact that people in local community live nearest, therefore understand the resources more than the outsider. In addition, they have inherent abilities to apply and adapt new and indigenous knowledge (Seesomonn, 2010). The fate of the IWRM in one watershed depends on the support and level of involvement of local communities. In IWRM the decision making power about the kind of project necessary, will reside with the local community, and believed that the management of the local water resources will be a holistic way of reducing sectoral interference.

Energy stored in flowing water can be used in many ways such as running water mills, power generation, irrigation, fisheries, and tourism. The community can decide for hydropower plant or irrigation project. The haphazard development of infrastructure disturbing water resources will be checked.

Hydropower relies on the water cycle, therefore understanding the water cycle is important to understand hydropower. Hydropower today occupies the foremost place among the renewable sources of energy in the world providing about $20 \%$ of the world's total energy. Water is a $100 \%$ 
clean, renewable resource, electricity from water power is far less expensive to produce than solar or wind power. Micro hydropower is one of the most environmentally benign energy conversion options available, because unlike large-scale hydro power, it does not attempt to interfere significantly with river flows. (Fraenkel,1991). Small scale hydropower stations combine the advantages of hydropower with those of decentralized power generation. They have more advantages inexpensive distribution of energy, limiting environmental costs as compared to large hydropower stations, independent of imported fuels and no need for expensive maintenance. Power generated with small hydro stations can be used for agro-processing, local lighting, water pumps and small businesses. The broad objective of the project was to study the community based Water Resource Development and its management through a social accounting system. This was achieved through following specific objectives:

- To study the major river systems and the present status of water budget of the entire Durlung watershed.

- To study the community partnership for water resource management.

- To study the potential feasibility of micro-hydropower sites.

\section{Description of Study Area}

The Durlung Watershed is comprised of the total of Chamranbesi VDC and some part of Milche VDC of Kavre District as well as some part of Thulo Durlung VDC, Chandanpur VDC and Kaleshor VDC of Lalitpur District This valley joins with Bagmati river in the south just adjacent to Makawanpur District. It is located at the foothills of Mahabharata range. Along the Mahabharata, village altitude varies from $1000 \mathrm{~m}$ (Dobhan Khola) to $2336 \mathrm{~m}$ (Go Bhangyang) above sea level. First habitation of Chamranbesi VDC named as Sano Durlun is located at south west of Kavre District. More accurately it ranges around North $27^{\circ} 30^{\prime} 00^{\prime \prime}$ to South $27^{\circ} 24^{\prime} 30^{\prime \prime}$ and East $85^{\circ} 28^{\prime}$ oo" to West $85^{\circ} 26^{\prime}$ oo". It is an hour's walk from Sano Durlung to Thulo Durlung which lies in Lalitpur District.

Durlung River, which separates Kavre and Lalitpur district, is one of the tributaries of Bagmati River. Durlung River is fed by small tributaries like Polsing River, Ghatte River, Rataun River, Chyang-Chyang River, Naman River, Gimda River, Khajuli River and Pakdole River, Dueuta River. Durlung watershed is divided into nine relatively homogeneous sub basins based on the principle flow path.

\section{Materials and Methods}

Socio-economic and Participatory Approach: Participatory research was followed by base line surveys. Survey questionnaire were used for personal interviews and focus group discussions. Nearly 40 $\%$ of household were covered by the survey from 4 different VDCs of Durlung watershed.

Several meetings were conducted in District Water Resource Committees (DWRC) of Kavre and
Dhulikhel district. Active participation of government was further enhanced by liasoning with Water and Energy Commission Secretariat (WECS), Government of Nepal. Thus a pillar of two ways participation from community level organization, such as Durlung Integrated Water Resource Management Committee (DIWRMC) and various water users groups to the governmental hierarchical organization of water resource management was maintained, as shown in the figure.
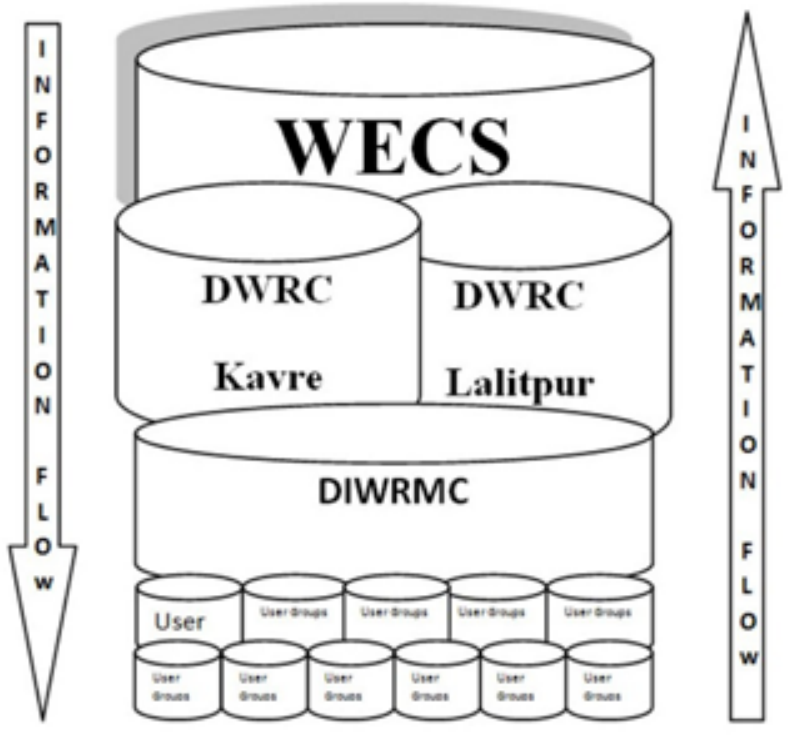

Figure 1: Information Flow in IWRM: Durlung Watershed

The communities of Durlung watershed have come up with the ideas of forming joint alliance with the Durlung Integrated Water Resource Committee (DIWRMC) for the wise use of water in the watershed. Schedule and regular meetings have given constitution (Bidhan) of the IWRM which was approved by Energy Commission Secretariat (WECS), District Water Resource Committee (DWRC), Kavre and Lalitpur districts, Durlung Integrated Water Resource Management Committee (DIWRMC), Village Development Committees (VDCs) and Kathmandu University.

Hydrological and Meteorological Data Collection: Detailed hydrology surveys were conducted by various methods such as salt dilution, floating, use of current meter, and slope-area. Data was collected in 3 major season, pre-monsoon, monsoon and post monsoon with 3 replications locally made with a one meter long Shaft (LMS) fixed on the river side. An Automatic Weather Station (AWS) was established in Sano Durlung, Chamrangbesi VDC.

A small weather station was established in the school premises to measure the weather parameters like temperature, relative humidity, rainfall, maximumminimum temperatures and evaporation. Five students from the respective schools were nominated as 'Environment Alerts' supervised from the school and Durlung Integrated Water Resource Committee (DIWRMC) for Hydrological and meteorological data collection and publication. 
Hydrological Modeling: Partially distributed hydrological modeling technique was used to calculate the water budget of Durlung Watershed. TOPMODEL (Beven, K. J. \& Kirk 1979, Beven et.al. 1995) was used along with GRASS GIS (GRASS Development Team 2012) for Durlung watershed which has an area 62.73 $\mathrm{km}^{2}$, to estimate daily discharge of Durlung watershed. TOPMODEL was calibrated and validated in nearby Nakkhu watershed applied to Durlung watershed.

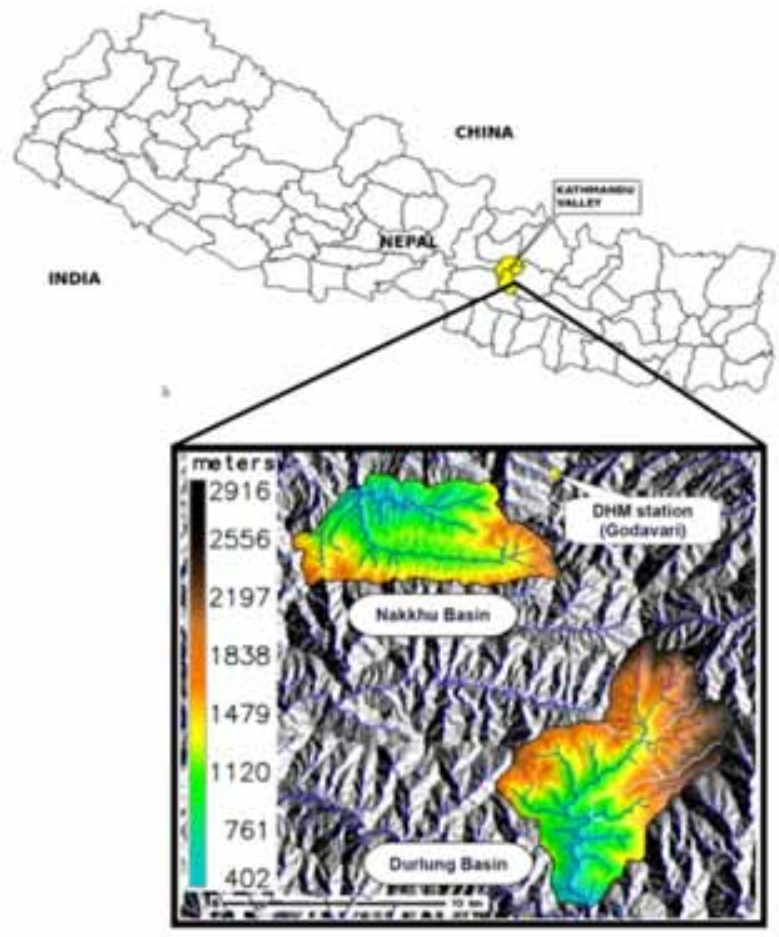

Figure 2: Locations of Climate Stations from Durlung Basin

\section{Micro-hydropower Feasibilities Studies}

Three different feasibility studies have been completed with total technical power generation. The best suitable site with complete pre-feasibility studies mainly relied on MIP tool of "Micro-hydropower Design Aids" designed by Small Hydropower Promotion Project (SHPP/GTZ) and Mini Grid Support Program (AEPC/ESAP 2001).

\section{Designing}

Site selection and design philosophy of the civil components of Deuta River Micro-hydro power Plant was detailed out with the specifications of design consideration of side intake, design consideration of diversion weir, design consideration for coarse trash rack, design consideration for settling basin, and design consideration for powerhouse.

\section{Finding and Implications \\ Water Resource Accounting}

Temporal flow of seasonal rivulet was estimated along with flowing time period and volume with a suitable mathematical model. Hydrological survey of the Durlung Khola and its tributaries on wet season of July and August, and dry season of December were measured. Water in Changchang reduced drastically in the winter than monsoon and was found to be not feasible to plan for a project with continuous use of water throughout a year.

\begin{tabular}{|l|c|c|}
\hline River Name & $\begin{array}{c}\text { Discharge in Wet } \\
\text { Season (Ips) }\end{array}$ & $\begin{array}{c}\text { Discharge in Dry } \\
\text { Seasons (Ips) }\end{array}$ \\
\hline Thulo & 267 & 220 \\
\hline Rataun & 250 & 160 \\
\hline Chyang-Chyang & 2364 & 211 \\
\hline
\end{tabular}

Table 1: Discharge of Durlung Tributaries

TOPMODEL was applied to Thulo, Chyang-Chyang sub-watershed, Rataun sub-watershed with the same input and parameters to sub-watershed and the whole watershed. Areas having same topographic index value are assumed to behave hydrologically in similar way. Topographic index is scale dependent so there is need of high quality resolution Digital Elevation Model (DEM) without sinks. Resolution recommended is less than $50 \mathrm{~m}$. DEM data and a sequence of rainfall and potential evapo-transpiration data are the inputs for the model and it predicts the resulting stream discharges. The validated model with Nash efficiency of 93 percent shows that the parameters selected were suitable and able to represent rainfall runoff process efficiently in Durlung watershed. After validation the daily discharge of Durlung watershed and subwatershed are listed in Table 2.

\begin{tabular}{|l|c|}
\hline $\begin{array}{c}\text { Watershed and } \\
\text { Sub-Watershed }\end{array}$ & Average Daily Discharge (MLD) \\
\hline Durlung & 157 \\
\hline Rataun & 19.5 \\
\hline Chyang Chyang & 17.9 \\
\hline Thulo & 13.3 \\
\hline
\end{tabular}

Table 2: The Average Daily Discharge of Durlung Watershed and three Sub-watershed

\section{Human Dimensions and Capabilities to}

\section{Manage Resource}

Seventy eight percent of population live in nuclear families, $62 \%$ of people are Buddhist. The main responding groups are males (91\%) with only about $4 \%$ of total population educated. $98 \%$ live on farming and animal husbandry. Average annual income is less then 750 \$. $93 \%$ of farm lands are rain-fed, animals per household counted as one goat and one cattle (buffalo/ Cow). Main agricultural constraint is water for irrigation. Main source of energy for domestic use are fuel wood and kerosene while electricity is merely used for lighting, radio, television, mobile phone recharge. Major environmental problems are landslides; and area covered by forest and agro forestry is $60 \%$ of the total land. People are actively enhancing development by getting involved with various local organizations formed by themselves such as economic (36\%), agricultural (33\%) and social (31\%). These results show that the area is very rich in natural resources, yet the people are poor; though with the development of local institutions people are motivated to brings sustainable development. On the question of knowledge, policy regarding water resource is lacking among local inhabitants and VDCs officials. Whereas DDC officials say they do follow the 
government mandates like Water Resource Act 2049 and other national water policies of the government. Based on that, Micro hydro is encouraged and prioritized for local community based organizations for preservation and optimum use. DWRC was very positive about the implementation of IWRM in Kavre and Lalitpur district with the need of Multiple Use of Water Master Plan in the district. Water Resources need to be managed in an integrated way with adequate study and careful observation of all factors, practically rather than theoretically. Every month, especially when proposals for any water use activities are obtained from user groups, VDC secretaries are called along with stakeholders to the meeting of DWRC. In trans-boundary issues, the decision is made with a public mandate.

Durlung Integrated Water Resource Management is a demand driven research project. The concept was initiated by the locals and was supported by Kathmandu University (KU) and University Grant Commission (UGC). It was further adopted by Water and Energy Commission Secretariat (WECS) as the first pilot project in IWRM. DWRC from Lalitpur and Kavre districts have also shown keen interest in the participation of piloting the IWRM in the Durlung Watershed. Full strength of participation at the village and community level was shown with the involvement of water related user groups for the selection of the

\begin{tabular}{|l|c|c|c|c|c|}
\hline \multicolumn{1}{|c|}{ Description } & Site 1 & Site 2 & Site 3 & Site 4 & Site 5 \\
\hline Stream & Rataun & Durlun & Naman & Deuta & Gimda \\
\hline Location & Tesro bato & Hathigauda & Chandanpur: 5 & Thuldadurlung & Thuladurlung:2 \\
\hline Catchment Area & $5.2 \mathrm{~km}^{2}$ & $24.45 \mathrm{~km}^{2}$ & $3.18 \mathrm{~km}^{2}$ & $5.2 \mathrm{~km}^{2}$ & $4 \mathrm{~km}^{2}$ \\
\hline Measured Discharge & $181 \mathrm{lps}$ & $391 \mathrm{lps}$ & $26.6 \mathrm{lps}$ & $42.04 \mathrm{lps}$ & $32.8 \mathrm{lps}$ \\
\hline Design Discharge & $90 \mathrm{lps}$ & $160 \mathrm{lps}$ & $8.6 \mathrm{lps}$ & $20 \mathrm{lps}$ & $10.72 \mathrm{lps}$ \\
\hline $\begin{array}{l}\text { Length of power } \\
\text { canal/tunnel }\end{array}$ & $800 \mathrm{~m}$ & $2625 \mathrm{~m}$ & $550 \mathrm{~m}$ & $650 \mathrm{~m}$ & $620 \mathrm{~m}$ \\
\hline Head & $133 \mathrm{~m}$ & $200 \mathrm{~m}$ & $63 \mathrm{~m}$ & $95 \mathrm{~m}$ & $82 \mathrm{~m}$ \\
\hline Theoretical power & $48.15 \mathrm{~kW}$ & $160 \mathrm{~kW}$ & $2.3 \mathrm{~kW}$ & $8.38 \mathrm{~kW}$ & $3.88 \mathrm{~kW}$ \\
\hline Economic feasibility & Feasible & Costly & Feasible & Feasible & Feasible \\
\hline Physical feasibility & Feasible & Feasible & Not feasible & Feasible & Not feasible \\
\hline Technical Feasibility & & & Feasible & Feasible & Feasible \\
\hline
\end{tabular}

member of Durlung Table 3: Comparative Site selection Study among Five Sites

Integratd Water

Resource Management Committee (DIWRMC). It has shown the tremendous participation from all the hierarchical sectors for the water resource development studies.

DIWRMC is formed by representatives from water user groups and associates. Water users from any group interested having proven one's capacity in locality was sent to the VDC for the election of DIWRMC members. Thus 19 selected member represented their areas in the DIWRMC for the holistic management of water equitable to all the clusters, gender, castes etc. Remarkable selection of key personnel to hold the charge of water resource management is demonstrated by DIWRMC. Competitive and aware representatives drafted a quality memorandum (Bidhan) of the committee. The memorandum is a binding document in which the objectives and working modality, work divisions among members, Vision, Mission, Plans, Policies and strategies of the committee are clearly mentioned. DIWRMC have identified their local needs, priorities, possibilities and objectives. The major objective of the memorandum are to protect the health of Durlung watershed ensuring optimum utilization of the water resources, cooperating with governmental and nongovernmental donor agencies, uplifting poverty of the area, production of hydropower and the right to sell the produced power.

From the meeting minutes of DIWRMC, it is found that $90 \%$ of the executive community members and $10 \%$ of other members were attending regularly. Also high level water professionals from Governmental sectors like WECS, CDOs, LDOs, were found to be linked with the IWRM project implementation. Around 25\% of the total people, as key persons were found actively involved in Integrated Water Resource Management activities. These key persons or quality persons motivated and led other people, which made the attitude of the whole watershed positive.

This pilot study done under the institutional frame work of Water and Energy Commission Secretariat (WECS) has shown positive response for the insertion of Integrated Water Resource Management Committee

(IWRMC) as a body for coordinating institutions between district level organizations (DWRC) and local level organizations (User Groups). IWRMC is a committee of local user groups and representatives from all the parts of the watershed which is aimed to coordinate all the water use sectors and promote holistic development by ensuring Multiple Uses of Water.

\section{Scheme of Water Resource Use and Feasibilities Studies of Hydropower Production}

There are several sites identified for pico and micro hydropower. For micro hydropower Durlung, Ratun, Thulo and Chyang-chyang rivers of Chamrangbesi VDC and Deuta, Naman and Gimda rivers of Lalitpur VDC were studied in detail (Table 3). Pico hydropower sites were identified at the Syapredanda of Jhingedanda Chyamrangbesi where two consecutive streams can be utilized for multiple uses. Micro and Picohydropower can be seen as an effective means of rural electrification, capable of bringing socio-economic progress to the rural populace in the villages.

The hydropower potential of Durlung basin is $67.1985 \mathrm{~kW}$ and $285.73 \mathrm{~kW}$ for Q80 and Q40 discharge respectively. Similarly Chyang Chyang river, Rataun 
river and Thulo river have the hydropower potential of $7.67 \mathrm{~kW}, 8.37 \mathrm{~kW}$ and $7.67 \mathrm{~kW}$ respectively at Q80 discharge.

In Lalitpur district Deuta river was seen as the best alternative. This is because the power generated was enough to meet the power demand of Ward no. 3, 4 and 5 of Chyamrangbesi VDC. The powerhouse is located $10 \mathrm{~m}$ above the downstream river water level. The water from the tailrace can be used for many different purposes like grinding mills and irrigation, which in turn upgrade the productivity of power and the cash crops. This is found to be economically and socially favorable.

In Kavre district Rataun River was found be the best. It was because the power generated was enough to meet the power demand of the VDC. Being near, transportation costs come to be lower than for Durlun River. Development of micro hydropower project in Rataun River will provide irrigation from its tailrace for 3 hector of land in Kalyansimha Gaon.

\section{Conclusions and Recommendations}

Average daily discharge of the Durlung Watershed was estimated at 157 Million Liters by Hydrological Modeling in GRASS GIS software. For further modeling it would be better if we use $10 \mathrm{~m}$ resolution DEM. Due to unavailability of frequent discharge data of sub watershed, comparing the observed and simulated discharges was not possible though some measured discharge data were well predicted by the Model.

The baseline survey suggested that the general impressions of the household are rural poor depending on agriculture lacking irrigation facility yet people are having access to drinking water supply in each house. Firewood is the primary source of energy for all purposes and electricity is the primary source for lighting. Kerosene is still used as a secondary source of energy. Landslide is the biggest environmental problem followed by uncertain weather changes, and seasonal water scarcity. Study shows most of the inhabitants, VDC secretaries and local authorities have no idea about IWRM, yet, they agreed to the main frame of IWRM. The relationship between VDCs and DDCs regarding water use is not very regular. The minutes and meetings of DIWRMC depict Durlung Integrated Water Resource Management Project was initiated under local efforts, had good sense of community interest accompanied by the willingness to participate for the project activities with good understanding and enthusiasm.

VDCs like Chandanpur, Chyamranbesi and Thulo Durlung having rivers like Ratan, Durlung, Changchang, Naman, Gimda and Deuta have huge potential for rural electrification through the off grid system. Detailed study discovers that Micro-hydropower in Ratan and Deuta River has multidimensional positive impacts on socio-economic development of the region. With the given socioeconomic conditions, topographical variations and available technical feasibility, the study shows that Micro-hydropower is a promising technology for rural development.

\section{Thus the Recommendations are:}

Irrigation facility is the prime need of the people of the area. Therefore, IWRM implementation should focus on ways to provide irrigation facilities to the local people. Hydropower production is given more emphasis by the DIWRMC for economic benefits. A complete package of power production and sale has to be developed for the area. The economic condition is mainly dependent on agricultural products. Complete packaged trainings on organic farming need to be delivered for the farmers to perform organic farming with confidence in the productivity. Landslides are the major problem of the area accelerated by unscientific construction of roads on hilly slopes. Therefore, awareness to stop such road construction should be given with the encouragement of road construction with detailed engineering design and good trail selection. There should be a provision for IWRMC to work and suggest suitable solution for water resource development for different user groups. All the water User groups' members should be involved as members of IWRMC. Formation of IWRMC is necessary in the watersheds for IWRM implementation. State should mention IWRM clearly in laws, policies and strategies which should be followed by line agencies. Rules and Regulations should be made properly from policy formation to implementation aspects. The framework of memorandum of IWRMC should be uniform for the whole country. Integrated Water Resource Management should be promoted by forming a user's committee under DIWRMC to utilize the water discharged from the tailrace after the Microhydropower development in the aforementioned VDCs. Training and adequate research are needed for enhancing the use of local materials to reduce the initial cost of hydraulic components. Co-ordination among different sectors is needed for the synthesis of the available information and more study should be done with the co-operation of local people, government bodies, NGOs. Gauging station should be established at major resource points for accurate data measurement. IWRMC should proceed to get the greater potential from Ratan, Durlung and Deuta River by the initiation of further studies and funding opportunities.

\section{Aknowlegdement}

Sincere thanks to University Grant Commission (UGC), the authority and staff of School of Arts, School of Science and School of Engineering, Kathmandu University (KU), Water and Energy Commission Secretariat (WECS), Water Resource Management Committee (WRMC) of Kavre and Lalitpur district, Durlung Integrated Water Resource Committee (DIWRMC), all the team members, research associates, students, volunteers, friends, and family members.

Sabita Aryal Khanna, Assistant Professor in Kathmandu University, Department of Environmental Science and Engineering. She has more than 20 years of experience in several international and national organizations of Nepal 
and India. She was team leader and principal investigator in the "Study on the opportunities for Water Resource Development through Social Accounting System in Durlung Watershed, Kavre, Nepal" awarded by UGC (funded by The World Bank) Nepal under the criteria of institutional research grant.

\section{Corresponding E-mail: sabita@ku.edu.np}

\section{References}

AEPC/ESAP (2001).Power Output Verification Guidelines for Micro-hydropower. Small Hydropower Promotion Project (SHPP/GTZ), Kathmandu, Nepal Alford, D. (1992). Hydrological aspects of the Himalayan region. International Centre for Integrated Mountain Development.

Bellamy, J.A. and A.K.L. Johnson, 2000, 'Integrated Resource Management: Moving from rhetoric to practice in Australian agriculture', Environmental Management Vol. 25 (3), pp. 265-280

Beven, K J, Lamb, R, Quinn, P F, Romanowicz, R and Freer, J, 1995 b, TOPMODEL, in V P Singh (Ed). Computer Models of Watershed Hydrology, Water Resources Publications, 1995, 627-668.

Beven, K. J. \& Kirkby, M. J. (1979), 'A physically based, variable contributing area model of basin hydrology', Hydrological Sciences Bulletin 24(1), 43--69.

Chenoweth, Jonathan L and Eran Feitelson Analysis of Factors Influencing Data and Information Exchange in International River Basins. Can Such Exchanges be used to Build Confidence in Cooperative Management? International Water Resources Association Water International, Volume 26, Number 4, Pages 499-512, 2001.

Conley,A. and Moote M.A., 2003. "Evaluating Collaborative Natural Resource Management." Society and Natural Resources 16: 371-386.

Cortner,H.J. and Moote,M.A. (1994). Trends and Issues in Land and Water Resources Management: Setting the Agenda for Change. Environmental Management, 18: 167-173.

Diana Suhardiman, Floriane Clement, Luna Bharati (2015) Integrated water resources management in Nepal: key stakeholders' perceptions and lessons learned, International Journal of Water Resources Development, Vol. 31, Iss. 2

Fraenkel, P., Paish, O., Bokalders, V., Harvey A., Brown, A., Edwards R. (1991). Micro-Hydro Power: a guide for development workers, London: IT Publications Ltd

Galaz, V. 2007. Water Governance, Resilience and Global Environmental Change: A Reassessment of Integrated Water Resources Management. Water Science and Technology 56: 1-9.

Global Partnership For Water, (February, 2004), IWRM Guidance

Global Water Partnership - Technical Advisory Committee (2010). Integrated Water Resources Management. TAC Background Papers No. 4, GWP, Stockholm, Sweden.

GRASS Development Team (2012), 'Geographic Resources Analysis Support System (GRASS GIS) Software', Open
Source Geospatial Foundation, USA. (http://grass. osgeo.org)

Gumbo, B., and Van der Zaag, P., 2002. Water losses and the political constraints to demand management: the case of the City of Mutare, Zimbabwe. Physics and Chemistry of the Earth 27: 805-813.

Gupta, J. (2004) (Inter)national Water Law and Governance: Paradigm Lost or Gained?, Inaugural Address as Professor of Policy and Law on Water Resources and the Environment, Department of Management and Institutions at the UNESCOIHE Institute for Water Education in Delft, The Netherlands, 22 March 2004; ISBN: 90-73445-11-6.

Hydro power Development Policy 2049(1992), Ministry of Water Resources, Kathmandu

IMF. (2006). Nepal : Poverty Reduction Strategy Paper, Annual Progress Report

Ingram,J. (2008) Agronomist-farmer knowledge encounters: an analysis of knowledge exchange in the context of best management practices in England. Agriculture and Human Values Volume 25 405-418 (3) Agronomist-farmer knowledge encounters

International Conference on Water and the Environment (ICWE 1992), The Dublin Statement and Report of the Conference, 26-31 January 1992, Dublin.

Jeffrey, P. and M. Gearey. 2006. Integrated water resources management: lost on the road from ambition to realisation? Water Science \& Technology 53 (1): 1-8

Kenge, J. G. (2009). Participatory watershed management to decrease land degradation and sediment transport in Kagera and Nyando catchments of Lake Victoria basin. (Student paper). Linköpings universitet.

Moriarty, P.; Butterworth, J. 2003. The productive use of domestic water supplies: How water supplies can play a wider role in livelihood improvement and poverty reduction. IRC Thematic Overview Paper. Delft, The Netherlands: International Water Supply and Sanitation Centre. Avaialble at: http://www. irc.nl/redir/content/ download/16138/208040/ file/Background\%2opaper\%20 symposium \% 20 Learning\%20Alliances.pdf

National Water Plan (2005).WECS, Government of Nepal , Kathmandu.

Ostrom E. (1990), Governing the Commons; the Evolution of Institutions for Collective Action, Cambridge University Press, Cambridge.

Quevauviller P (2010) Is IWRM achievable in practice? Attempts to break disciplinary and sectoral walls through a science-policy interfacing framework in the context of the EU Water Framework Directive. Irrig Drain Syst 24(3-4):177-189

Rowe,G. and L. J. Frewer, 2000. "Public Participation Methods: A Framework for Evaluation." Science, Technology, \& Human Values 25(1): 3-29.

Seesomonn, K. (2010). Participatory Watershed Management Process: A Case Study of Huai Mae Di Noi WAtershed, Ban Rai District,Uthai Thani Province, Kasetsart University 
Sharma. P. N, 1999. Participatory processes for integrated watershed management. Participatory Watershed Management Training in Asia (PWMTA) and Farmercentred Agricultural Resource Management (FARM) Programs, Netherlands/UNDP/FAO, GCP/RAS/161/ NET - RAS/93/o62.

Timmerman, J., J. Möltgen, and C. Pahl-Wostl. 2008. The adaptiveness of IWRM: analysing European IWRM research. IWA Publishing, London, UK.

UNDP. (2009). Human Development report, USA.

United Nations. The Millennium Development Goals Report 2012 (UN, 2012).

United Nations Country Team of Nepal, (UNCTN 2002). “MDG Nepal Progress Report, 2002." Accessed on 5/28/o4: http://www.un.org.np/publications/mdg/

Water Resources Act, 2049 (1992). Government of Nepal , Kathmandu.

Water Resource Regulation 2050 (1993) Government of Nepal , Kathmandu.

Water Resources Strategy (2002), WECS, Government of Nepal, Kathmandu.

WWC (2000) Final report: The Second World Water Forum and ministerial conference. The Hague, Ministry of Foreign Affairs

WWC (2003), Final Report: The Third World Water Forum, Tokyo, Secretariat of the Third World Water Forum 